\title{
STUDI TENTANG PENERAPAN ADMINISTRASI PERENCANAAN DAN PENGENDALIAN PRODUKSI PADA PT SANWA ENGINEERING BATAM
}

\author{
Putrhi Pranitha Napitu ${ }^{1}$ ), Dwi Kartikasari²) \\ 1) Prodi Administrasi Bisnis Terapan Politeknik Negeri Batam, email: putripranita66@gmail.com \\ 2) Prodi/Jurusan Administrasi Bisnis, Politeknik Negeri Batam, email: dwi@polibatam.ac.id
}

\begin{abstract}
This study aims to develop operational standards of administrative procedures of production planning and control in PT Sanwa Engineering Batam. Methods of data collection using method of documentation and structured interview to planner and customer service planner. While for data analysis using descriptive qualitative analysis and also SWOT analysis (Strengths, Weakness, Opportunity, and Threats) which discuss about how application of planning and controlling production at PT Sanwa Engineering Batam start from production planning, production scheduling, production supervision, related organizational functions and information and documents required. The results of this research is the formation of a flowchart of the administration process of planning and controlling new production in more detail so as to facilitate new employees to understand their work or the reader understand the principal activities of a staff of administration in the production department.
\end{abstract}

Keywords: Administration of production planning and control, standard operational procedures, SWOT analysis, flowchart.analisis SWOT, bagan alur (flowchart).

\begin{abstract}
Abstrak
Penelitian ini bertujuan untuk menyusun standar operasional prosedur administrasi perencanaan dan pengendalian produksi di PT Sanwa Engineering Batam. Metode pengumpulan data menggunakan metode dokumentasi dan wawancara terstruktur kepada planner dan costumer service planner. Sedangkan untuk analisis data menggunakan analisis kualitatif deskriptif dan juga analisis SWOT (Strengths, Weakness, Opportunity, and Threats) yang membahas tentang bagaimana penerapan administrasi perencanaan dan pengendalian produksi pada PT Sanwa Engineering Batam mulai dari perencanaan produksi, penjadwalan produksi, pengawasan produksi, fungsi-fungsi organisasi terkait dan informasi dan dokumen yang dibutuhkan. Hasil dari penelitian ini yaitu terbentuknya suatu bagan alur (flowchart) proses administrasi perencanaan dan pengendalian produksi yang baru secara lebih detail sehingga memudahkan karyawan baru untuk memahami pekerjaannya ataupun pihak pembaca memahami kegiatan pokok seorang staf sdministrasi di bagian produksi.
\end{abstract}

Kata kunci: Administrasi perencanaan dan pengendalian produksi, standar operasional prosedur, analisis SWOT, bagan alur (flowchart).

\section{PENDAHULUAN \\ Latar Belakang}

Sebagaimana yang telah diketahui bahwa suatu perusahaan manufaktur yang bertujuan untuk memproduksi suatu barang sudah selayaknya melakukan perencanaan dan pengendalian produksi yang baik dan terencana. Menurut Kusuma (2009:1) tujuan dari perencanaan dan pengendalian produksi adalah merencanakan dan mengendalikan aliran material ke dalam, di dalam pabrik, dan keluar pabrik sehingga posisi keuntungan optimal dapat dicapai oleh perusahaan. Dalam hal perencanaan dan pengendalian produksi diperlukan adanya suatu sistem yang merupakan acuan kegiatan/alur produksi yang akan dilaksanakan.

PT Sanwa Engineering Batam merupakan salah satu perusahaan manufaktur yang berlokasi di Kawasan Industrial Batamindo Muka Kuning yang berpusat pada PT Sanwa Plastic Industri Pte Ltd yang berlokasi di Singapura. Perusahaan ini bergerak dalam bidang produksi layanan manufaktur presisi yang terpadu. Dalam melakukan perencanaan produksi, PT Sanwa Engineering Batam 
merencanakan produksi berdasarkan permintaan costumer yang biasanya dikirim setiap 6 (enam) bulan sekali atau per tahun yang disebut dengan forecast. Setelah menerima forecast dari costumer selanjutnya bagian planner mengolah data dan menyusun jadwal produksi serta jumlah barang yang diproduksi berdasarkan sistem perencanaan yang diterapkan di PT Sanwa Engineering Batam yang kemudian menghasilkan jadwal produksi (Master Production Schedule/MPS).

Meskipun demikian, pada realisasinya, kegiatan produksi pada PT Sanwa Engineering Batam dituangkan dalam flowchart production planning yang faktanya hanya merupakan flowchart sederhana yang tidak menggambarkan prosedur detail dan aktual dari perencanaan dan pengendalian produksi saat ini karena disusun sudah cukup lama sekitar 7 tahun lalu tepatnya pada 19 Juli 2010. Oleh sebab itu, untuk kelancaran kegiatan produksi persusahaan, perlu dirancang sebuah flowchart production planning yang menjadi acuan kerja (work instruction) yang lebih faktual. Kegiatan penyusunan ulang/pembaharuan dari flowchart ini diperlukan agar lebih jelas terlihat alur setiap langkah/proses yang dilakukan mulai dari pesanan diterima hingga barang jadi tersebut dikirim. Maka tujuan utama penelitian ini adalah melakukan penelitian mengenai bagan alur proses produksi PT Sanwa Engineering Batam yang kemudian akan diolah ke dalam suatu flowchart yang lebih detail yang disusun dengan menggunakan Microsoft Visio.

\section{Rumusan Masalah}

Berdasarkan latar belakang yang telah dijabarkan di atas, maka penulis merumuskan masalah sebagai berikut :

1. Bagaimanakah penerapan administrasi perencanaan produksi pada PT Sanwa Engineering Batam Bagaimanakah penerapan administrasi penjadwalan produksi pada PT Sanwa Engineering Batam

2. Bagaimanakah penerapan administrasi pengawasan produksi pada PT Sanwa Engineering Batam khususnya untuk PT XYZ

3. Bagaimanakah fungsi-fungsi organisasi yang terkait proses penerapan administrasi perencanaan dan pengendalian produksi dilaksanakan pada PT Sanwa Engineering Batam

4. Apasajakah informasi dan dokumen yang diperlukan terkait administrasi perencanaan dan pengendalian produksi pada PT Sanwa Engineering Batam

5. Bagaimanakah pembuatan bagan alur prosedur administrasi perencanaan dan pengendalian produksi yang diterapkan pada PT Sanwa Engineering Batam

6. Apakah tinjauan praktis terhadap administrasi pada subsistem perencanaan dan pengendalian produksi pada PT Sanwa Engineering Batam

\section{Tujuan Penelitian}

Adapun tujuan dari penelitian ini adalah :

1. Untuk mengetahui bagaimanakah penerapan administrasi perencanaan produksi pada PT Sanwa Engineering Batam

2. Untuk mengetahui bagaimanakah penerapan administrasi penjadwalan produksi pada PT Sanwa Engineering Batam

3. Untuk mengetahui bagaimanakah penerapan administrasi pengawasan produksi pada PT Sanwa Engineering Batam

4. Untuk mengetahui bagaimanakah fungsifungsi organisasi yang terkait proses penerapan administrasi perencanaan dan pengendalian produksi dilaksanakan pada PT Sanwa Engineering Batam

5. Untuk mengetahui apasajakah informasi dan dokumen yang diperlukan terkait administrasi perencanaan dan pengendalian produksi pada PT Sanwa Engineering Batam Untuk mengetahui pembuatan bagan alur prosedur administrasi perencanaan dan pengendalian produksi yang diterapkan pada PT Sanwa Engineering Batam

6. Untuk mengetahui tinjauan praktis terhadap administrasi pada subsistem perencanaan dan pngendalian produksi pada PT Sanwa Engineering Batam

\section{Manfaat Penelitian}

Adapun manfaat yang dapat diperoleh dari penelitian ini antara lain:

1. Manfaat Praktis

Penulis berharap hasil penelitian ini dapat digunakan oleh perusahaan khususnya pada PT Sanwa Engineering Batam dalam 
Puthri \& Dwi, Studi tentang Penerapan Administrasi Perencanaan dan Pengendalian...

memberikan informasi mengenai penerapan administrasi perencanaan dan pengendalian produksi yang telah diterapkan dan juga sebagai acuan dalam menjelaskan prosedur perencanaan dan pengendalian produksi di bagian perencanaan dan pengendalian produksi (Production Planning Inventory Control/PPIC).

2. Manfaat teoritis

Penulis berharap hasil penelitian ini dapat digunakan sebagai bahan referensi dan sebagai bahan acuan penelitian yang serupa di masa yang akan datang. Penulis juga berharap agar penelitian ini dapat memberikan informasi tambahan yang

Tabel 1. Kajian Empiris

\begin{tabular}{|c|c|c|c|}
\hline & $\begin{array}{l}\text { Imm Penlliti } \\
\text { dan Thum }\end{array}$ & Jidull & Haxil \\
\hline & 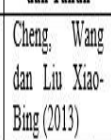 &  & 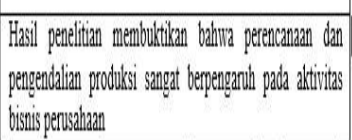 \\
\hline & 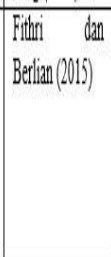 & 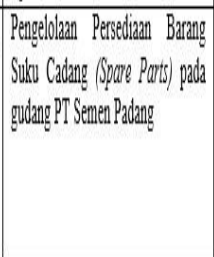 & 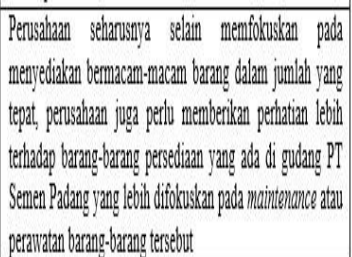 \\
\hline & 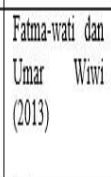 & 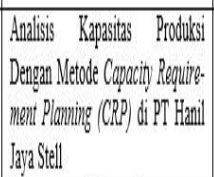 & 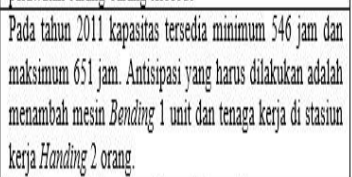 \\
\hline$A$ & 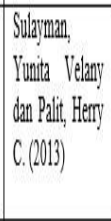 & 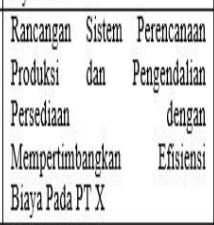 & 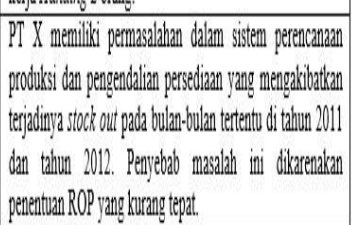 \\
\hline & 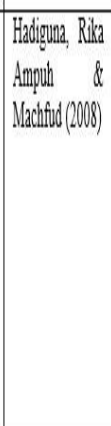 &  & 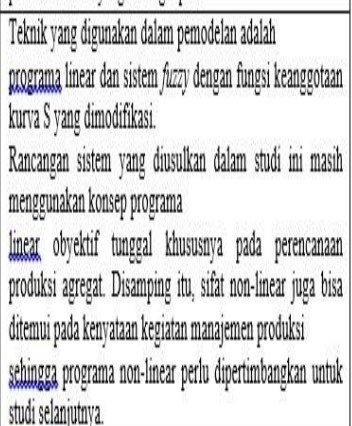 \\
\hline
\end{tabular}

\section{Kajian Teori}

\section{Pengertian Administrasi}

Menurut Kusdi (2011:7) administrasi dapat diartikan sebagai cara atau sarana untuk menggerakkan organisasi dengan tugas bermanfaat bagi pembaca dalam penerapan administrasi perencanaan dan pengendalian produksi yang diterapkan pada PT Sanwa Engineering Batam

\section{KAJIAN TEORI \\ Kajian Empiris}

Sebenarnya penelitian studi kasus tentang administrasi perencanaan produksi sangatlah terbatas, relatif terhadap evaluasi prosedur pembelian dan prosedur penjualan yang telah banyak tersedia dalam literatur yang ada. Diantara yang mendekati topik yang dibahas peneliti di antaranya:

mengarahkan organisasi mencapai tujuantujuan yang diinginkan. Menurut Fahmi (2015:1) administrasi adalah sebuah bangunan hubungan yang tertata secara sistematis yang membentuk sebuah jaringan yang saling bekerjasama satu sama lainnya untuk mendukung terwujudnya suatu mekanisme kerja yang tersusun dan mencapai tujuan yang diharapkan. Kegiatan administrasi produksi meliputi aspek-aspek sebagai berikut yaitu :

a. Perencanaan produk atau barang yang akan di produksi

b. Keputusan perencanaan kapasitas produksi

c. Sistem penyediaan, penyimpanan dan juga logistrik produksi

d. Perencanaan kebutuhan dan juga pengawasan kualitas produksi $(Q C)$

\section{Perencanaan dan Pengendalian Produksi}

Menurut Prihantoro (2012:122), secara garis besar proses produksi adalah kegiatan mengolah masukan (input yaitu sumber daya produksi) dalam proses dengan menggunakan metode tertentu untuk menghasilkan keluaran (output yaitu barang maupun jasa) yang sesuai dengan ketentuan.

\section{a. Perencanaan Produksi}

Menurut Siswandi (2011:43), pada umumnya perencanaan dapat dibedakan ke dalam :

\section{Perencanaan Menurut Waktu}

Perencanaan menurut waktu dapat dibedakan yaitu perencanaan jangka pendek adalah perencanaan yang pelaksanaannya memerlukan waktu paling lama setahun, perencanaan jangka menengah adalah perencanaan yang jangka waktu 
pelaksanaannya lebih dari setahun akan tetapi kurang dari 5 tahun dan perencanaan jangka panjang adalah perencanaan yang waktu pelaksanaannya adalah lebih dari setahun.

\section{Perencanaan Menurut Fungsi}

Perencanaan menurut fungsi adalah perencanaan yang dikelompokkan menurut bagian (unsur-unsur) penting dan utama yang ada di dalam suatu organisasi yang meliputi fungsi produksi, fungsi umum, fungsi pemasaran, fungsi keuangan, fungsi sumber daya manusia, fungsi riset dan fungsi pengembangan.

\section{Perencanaan Menurut Pusat}

\section{Pertanggungjawaban}

Di dalam organisasi bisnis, masingmasing bagian seperti bagian yang bertanggungjawab terhadap penghasilan membuat perencanaan, bagian yang bertanggungjawab terhadap biaya membuat perencanaan dan selanjutnya.

\section{Perencanaan Menurut Penggunaan}

Dari segi penggunaan, perencanaan dibedakan ke dalam perencanaan satu langkah yaitu perencanaan di mana implementasinya hanya dikerjakan satu periode implementasinya dan perencanaan

berkelanjutan yaitu perencanaan yang pelaksanaannya akan berkelanjutan (diulang) pada periode berikutnya.

\section{Perencanaan Dalam Kaitannya dengan Strategi}

Dalam kaitannya dengan strategi, perencanaan dibedakan ke dalam perencanaan strategi dan perencanaan taktis. Perencanaan strategis berkaitan dengan perencanaan yang bermuatan luas dan menyeluruh serta bersifat jangka panjang sejalan dengan tujuan dan misi organisasi sedangkan perencanan taktis adalah perencanaan yang memusatkan kepada tindakan atau aktivitas sehari-hari.

\section{b. Penjadwalan Produksi}

\section{Menurut Deitiana}

(2011:230), perencanaan agregat atau penjadwalan agregat merupakan sebuah pendekatan untuk menentukan kuantitas dan waktu produksi pada jangka menengah (biasanya 3 hingga 18 bulan ke depan). Penjadwalan produksi berimplikasi pada hal-hal berikut, yaitu :

- Pada penggunaan aset yang dimiliki perusahaan menjadi efektif sehingga investasi yang ditanamkan perusahaan akan memberikan hasil yang optimal

- Kapasitas yang digunakan akan lebih terukur sehingga jumlah output dapat dipastikan dan pelayanan kepada konsumen dapat lebih baik dari sebelumnya

- Pada akhirnya akan lebih cepat pengiriman produk tersebut kepada konsumen yang berarti keunggulan kompetitif bagi perusahaan dalam pelayanan yang cepat dapat tercapai.

\section{c. Pengawasan Produksi}

Menurut Siwandi

$(2011 ; 195)$, pengawasan dapat didefinisikan sebagai proses untuk "menjamin" bahwa tujuan-tujuan dari suatu organisasi dan manajemen tercapai. Ini berkenaan dengan cara-cara membuat kegiatan-kegiatan sesuai dengan yang direncanakan. Pengawasan membantu penilaian apakah perencanaan, pengorganisasian, penyusunan, dan pengarahan telah dilaksanakan secara efektif.

\section{Fungsi-fungsi Organisasi}

Menurut Ridhotullah dan Jauhar (2015:1), terdapat 4 fungsi utama dalam manajemen, yaitu :

\section{a. Perencanaan (planning)}

Dalam manajemen, perencanaan adalah proses mendefinisikan tujuan organisasi, membuat sebuah strategi untuk mencapai tujuan yang dharapkan, dan mengembangkan rencana aktivitas kerja organisasi.

\section{b. Pengorganisasian (organizing)}

Proses yang menyangkut bagaimana strategi dan taktik yang telah dirumuskan dalam perencanaan didesain dalam sebuah struktur organisasi yang tepat, sistem dan juga lingkungan organisasi yang kondusif, dan dapat memastikan bahwa semua pihak dalam organisasi tetap bekerja secara efektif dan efisien guna pencapaian tujuan organisasi tersebut

\section{c. Pengarahan (actuating/directing)}

Proses implementasi program agar dapat dijalankan oleh seluruh pihak dalam organisasi serta proses memotivasi agar semua pihak dapat menjalankan tanggungjawabnya dengan penuh kesadaran dan produktivitas yang tinggi.

d. Pengawasan (controlling) 
Puthri \& Dwi, Studi tentang Penerapan Administrasi Perencanaan dan Pengendalian...

Proses yang dilakukan untuk memastikan seluruh rangkaian kegiatankegiatan yang telah direncanakan, diorganisasikan dan diimplementasikan dapat berjalan sesuai dengan target yang diharapkan sekalipun berbagai perubahan terjadi dalam lingkungan dunia bisnis yang dihadapi.

\section{Analisis SWOT}

Menurut Rangkuti (2015:20), penelitian menunjukkan bahwa kinerja perusahaan dapat ditentukan oleh kombinasi faktor internal dan faktor eksternal. Faktor internal dan eksternal tersebut harus dipertimbangkan dalam analisis SWOT. SWOT adalah singkatan dari lingkungan internal strengths dan weakness serta lingkungan eksternal opportunities dan threats yang dihadapi dunia bisnis. Sebuah analisis SWOT membandingkan antara faktor eksternal peluang (opportunities) dan ancaman (threats) dengan faktor internal kekuatan (strengths), dan kelemahan (weakness).

\section{Kerangka Pemikiran}

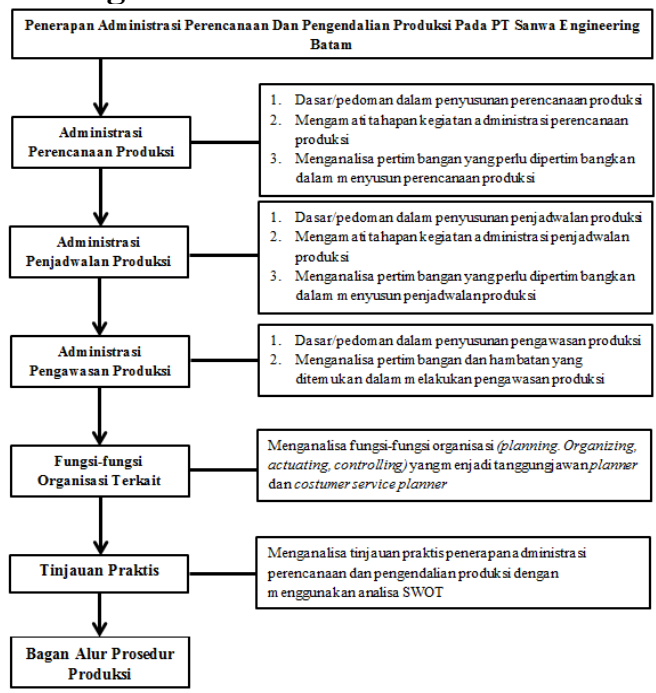

Gambar 1. Kerangka Pemikiran

\section{METODE}

\section{Rancangan Penelitian}

Rancangan penelitian menggunakan metode deskriptif kualitatif dan menggunakan Microsoft Visio untuk pembuatan flowchart/bagan alur prosedur administrasi perencanaan dan pengendalian produksi PT Sanwa Engineering Batam. Tujuan dari penelitian deskriptif kualitatif adalah untuk mengungkapkan kejadian atau fakta dan keadaan yang terjadi saat penelitian berlangsung sehingga dapat menjawab pertanyaan yang telah dikemukakan dalam rumusan masalah dengan cara mengolah atau menganalisis hasil penelitian.

\section{Informan/Subjek Penelitian}

Jumlah informan/subjek yang dipilih yaitu hanya 2 dikarenakan berfokus pada salah satu costumer PT Sanwa Engineering Batam yaitu PT XYZ. Adapun kriteria informan/subjek penelitian yang dikategorikan dalam penelitian ini adalah:

a. Responden adalah karyawan yang bekerja di bagian/departemen PC pada PT Sanwa Engineering Batam

b. Responden memiliki jabatan dan tugas dalam merencanakan dan mengendalikan produksi

c. Responden memiliki tugas dan tanggung jawab yang mendukung sebagai costumer service planner khusus untuk PT XYZ

\section{Teknik Pengumpulan Data}

Metode pengumpulan data yang digunakan dalam penelitian ini yaitu metode wawancara terstruktur, metode observasi dan metode dokumentasi. Metode wawancara terstruktur yaitu teknik pengumpulan data yang dilakukan melalui tatap muka dan tanya jawab langsung antara peneliti dengan narasumber dan peneliti telah mengetahui dengan pasti apa saja informasi yang ingin digali/ditanyakan kepada responden/narasumber secara sistematis. Metode dokumentasi yaitu teknik pengumpulan data dengan mencari data yang dapat berbentuk gambar, tulisan, dan lain-lain yang mendukung sebagai informasi dalam suatu penelitian

\section{Metode Analisis dan Tahapan Pengolahan Data}

Teknik analisis yang digunakan dalam penelitian ini yaitu analisis kualitatif deskriptif untuk menganalisis penerapan administrasi perencanaan dan pengendalian produksi pada PT Sanwa Engineering Batam. Tahapan pengolahan data yang dilakukan pada penelitian ini yaitu :
1. Analisis penerapan administrasi perencanaan kapasitas dan juga tahapan 
atau langkah-langkah yang dilakukan dalam administrasi proses perencanaan produksi pada PT Sanwa Engineering Batam

2. Analisis penerapan administrasi penjadwalan produksi dan juga tahapan atau langkah-langkah yang dilakukan dalam administrasi proses penjadwalan produksi pada PT Sanwa Engineering Batam

3. Analisis penerapan administrasi pengawasan produksi dan juga tahapan atau langkah-langkah yang dilakukan dalam administrasi proses pengawasan produksi pada PT Sanwa Engineering Batam

4. Analisis penerapan fungsi-fungsi organisasi pada bagian PC (Production Control) di PT Sanwa Engineering Batam

5. Analisis informasi dan dokumen apa saja yang diperlukan terkait administrasi perencanaan dan pengendalian produksi pada PT Sanwa Engineering Batam

6. Pembuatan atau perancangan bagan alur prosedur administrasi perencanaan dan pengendalian produksi hingga barang tersebut dikirim ke PT XYZ sebagai salah satu costumer yang diterapkan pada PT Sanwa Engineering Batam, studi kasus melalui salah satu costumer yang paling sering memesan part dari PT Sanwa Engineering Batam yaitu PT XYZ.

7. Analisis tinjauan praktis terhadap administrasi pada sub sistem perencanaan dan pengendalian produksi pada PT Sanwa Engineering Batam melalui analisis SWOT

\section{HASIL DAN PEMBAHASAN}

\section{Penerapan Administrasi Perencanaan}

\section{Produksi}

a. Tujuan

Membuat suatu rencana produksi yang baik dan sesuai dengan kebutuhan agar dapat memenuhi permintaan costumer dan membuat costumer merasa puas.

\section{b. Ruang Lingkup}

Disusun oleh costumer service planner dan planner dan berlaku hanya pada bagian production control (PC).

\section{c. Istilah/Singkatan/Definisi}

PO : Purchase Order

FG : Finish Goods

CS : Costumer Service

\section{d. Referensi}

Purchase Order

Forecast

Bill of Material (BOM)

Daily Delivery Schedule

e. Lampiran

Purchase Order

Forecast

Daily Delivery Schedule

PO Revised

f. Sub-Prosedur

-

g. Uraian Prosedur

Gambar 1 Flowchart Administrasi Perencanaan Produksi

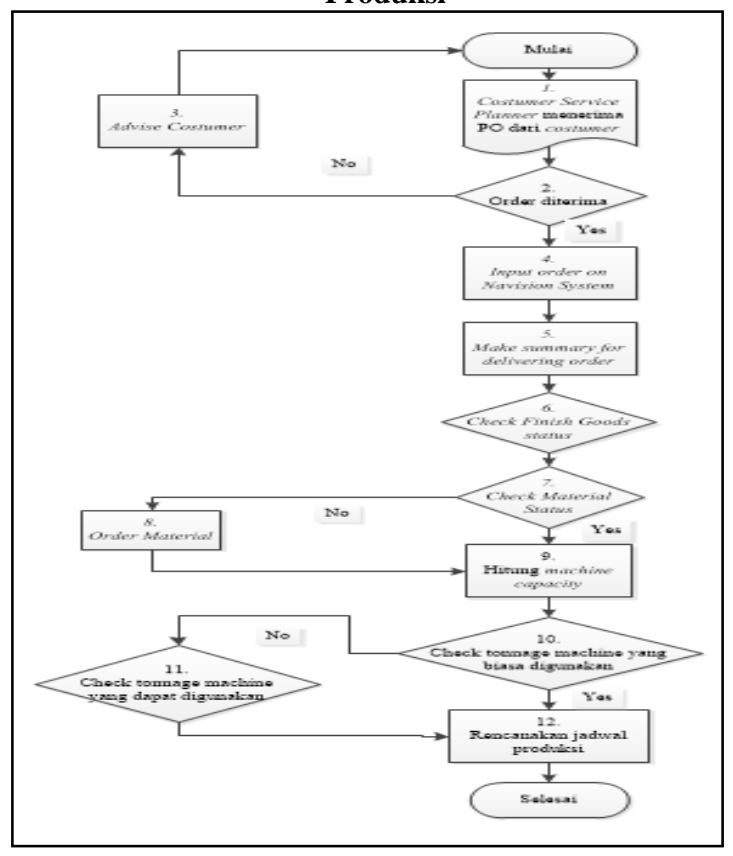

Sumber : Hasil Penelitian 
Puthri \& Dwi, Studi tentang Penerapan Administrasi Perencanaan dan Pengendalian...

\begin{tabular}{|c|c|c|c|}
\hline Uraian & PIC & Masukan & Keluaran \\
\hline 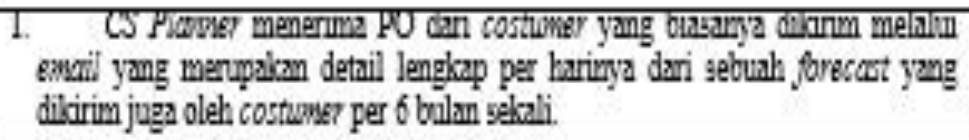 & $\begin{array}{l}\text { CS } \\
\text { Plowner }\end{array}$ & $\begin{array}{l}\text { PO, } \\
\text { Forecast }\end{array}$ & \\
\hline 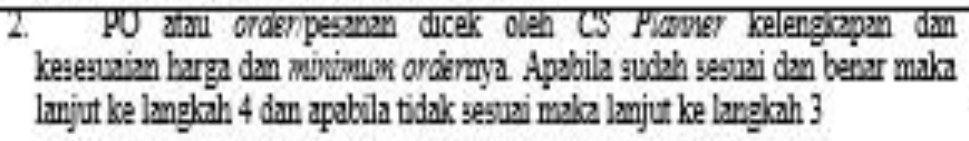 & $\begin{array}{l}\text { CS } \\
\text { Planer }\end{array}$ & PO & \\
\hline 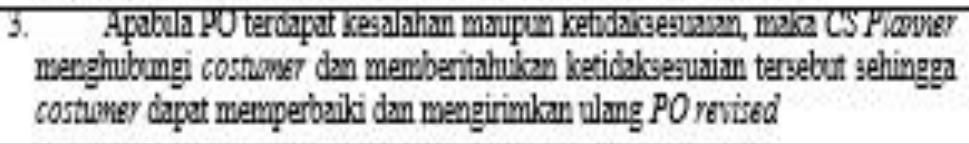 & $\begin{array}{l}\text { CS } \\
\text { Plaver }\end{array}$ & & PORevised \\
\hline 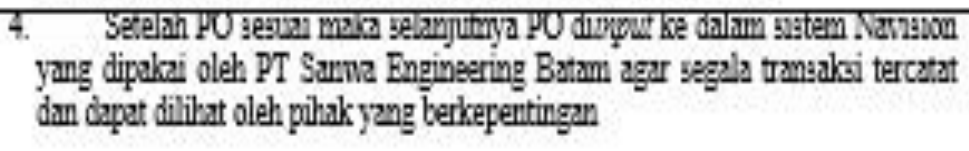 & $\begin{array}{l}\text { CS } \\
\text { Pianner }\end{array}$ & PO & $\begin{array}{l}\text { PO on } \\
\text { Nerision } \\
\text { System }\end{array}$ \\
\hline 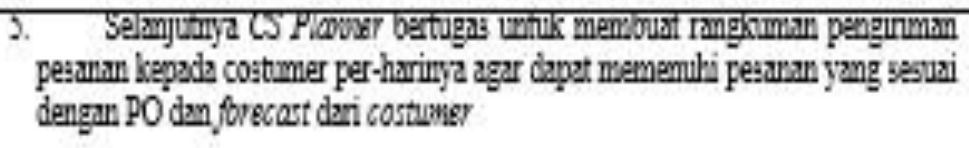 & $\begin{array}{l}\text { CS } \\
\text { Ploner }\end{array}$ & PO & $\begin{array}{l}\text { Doily } \\
\text { Deiney } \\
\text { Schedise }\end{array}$ \\
\hline 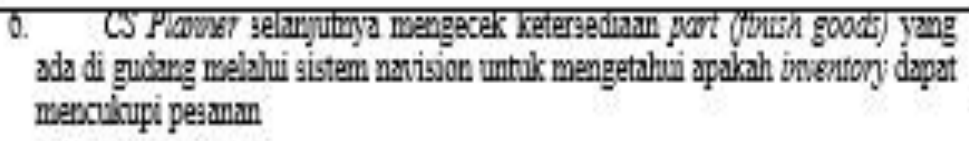 & $\begin{array}{l}\text { CS } \\
\text { Pianer }\end{array}$ & & \\
\hline 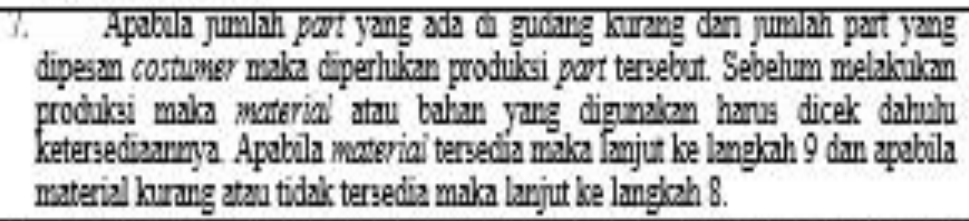 & $\begin{array}{l}\text { CS } \\
\text { Pianer }\end{array}$ & & \\
\hline 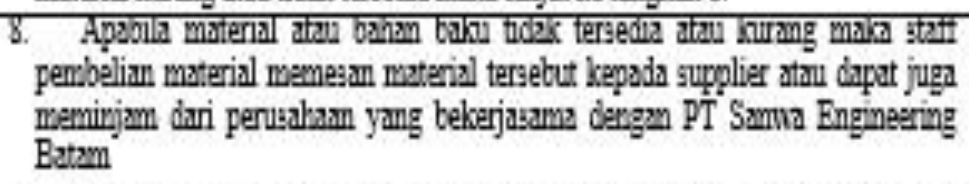 & $\begin{array}{l}\text { Thaterial } \\
\text { Stafi }\end{array}$ & & \\
\hline 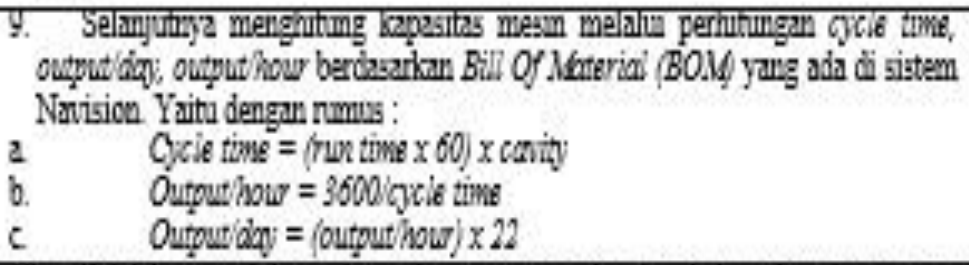 & PXover & $\begin{array}{l}\text { Bill Of } \\
\text { Merarial } \\
\text { BOM }\end{array}$ & \\
\hline 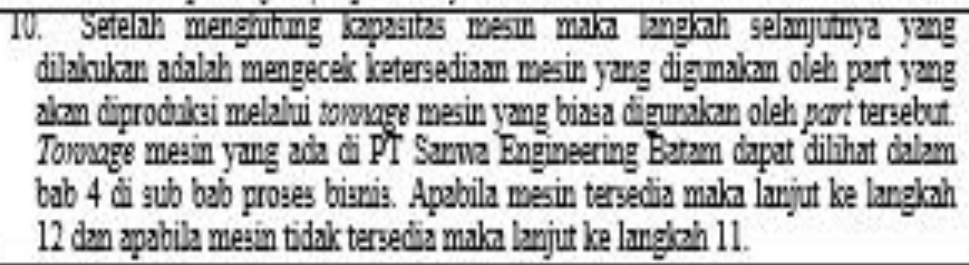 & Phover & & \\
\hline 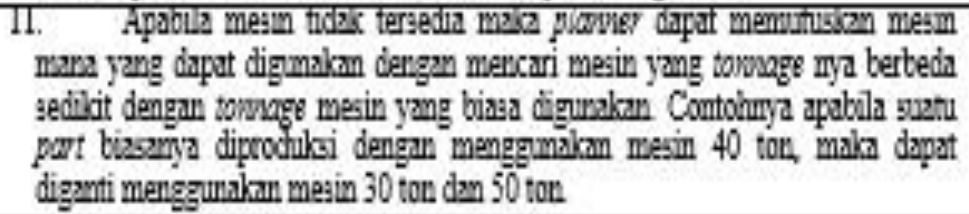 & Planer & & \\
\hline 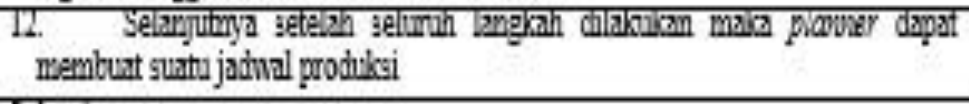 & Plaver & & \\
\hline Seles & & & \\
\hline
\end{tabular}


h. Penyimpanan Dokumen dan Rekaman

\begin{tabular}{|c|c|c|c|}
\hline No. & Dokumen/Rekaman & $\begin{array}{c}\text { Lokasi } \\
\text { Penyimpanan }\end{array}$ & Period \\
\hline 1. & Forecast & $\begin{array}{c}P C \\
\text { (Production } \\
\text { Control) }\end{array}$ & 5 years \\
\hline 2. & PO (Purchase Order) & $\begin{array}{c}P C \\
\text { (Production } \\
\text { Control) }\end{array}$ & 5 years \\
\hline 3. & PO Revised & $\begin{array}{c}P C \\
\text { (Production }\end{array}$ & 5 tahun \\
\hline 4. & $\begin{array}{l}\text { Daily } \\
\text { Schedule }\end{array}$ & $\begin{array}{c}\text { Control) } \\
\text { PC } \\
\text { (Production } \\
\text { Control) }\end{array}$ & 5 tahun \\
\hline
\end{tabular}

\section{Penerapan Administrasi Penjadwalan} Produksi

\section{a. Tujuan}

Menyusun suatu jadwal produksi yang baik dan terencana setiap harinya atau yang biasa disebut daily production schedule agar prosess produksi dapat dilakukan seefektif dan seefisien mungkin sehingga dapat memenuhi permintaan dari costumer tepat waktu.

\section{b. Ruang Lingkup}

Disusun oleh planner di bagian production control $(P C)$ yang selanjutnya diserahkan kepada bagian production office, leader production, quality control ( $Q C)$, dan store.

c. Istilah/Singkatan/Definisi

FG : Finish Goods

CS : Costumer Service

d. Referensi

Purchase Order

Forecast

Bill of Material (BOM)

Machine Capacity

e. Lampiran

Purchase Order

Forecast

Machine Capacity

f. Sub-Prosedur

-

g. Uraian Prosedur
Gambar 2 Flowchart Administrasi Penjadwalan Produksi

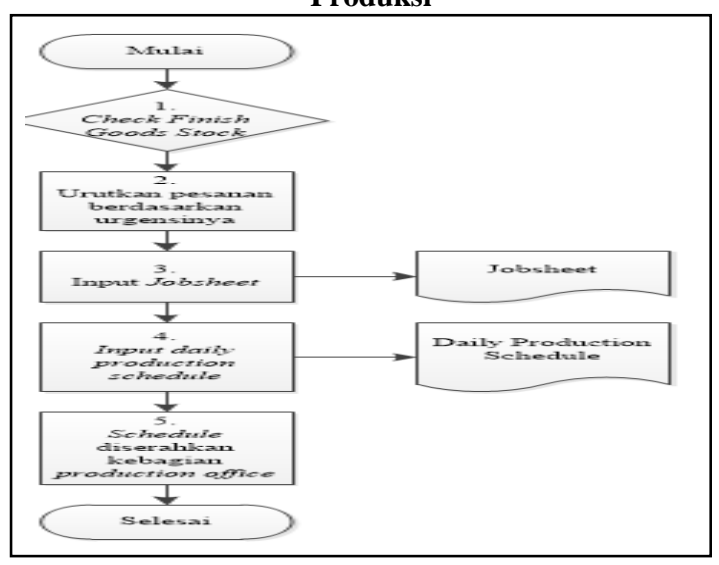

Sumber : Hasil Penelitian 
Puthri \& Dwi, Studi tentang Penerapan Administrasi Perencanaan dan Pengendalian...

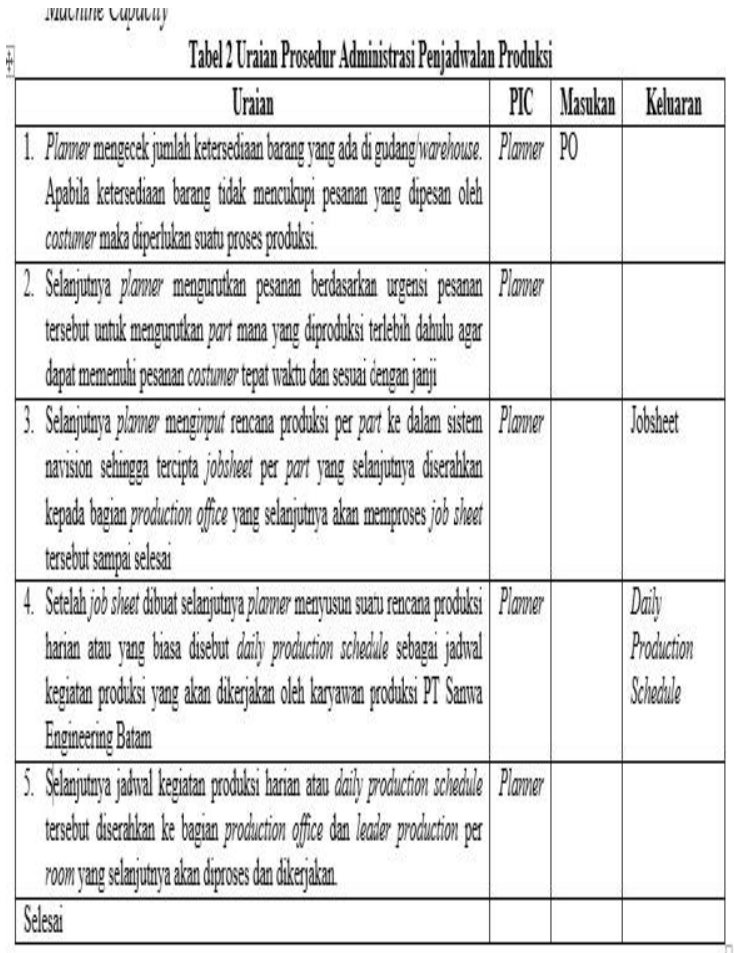

Sumber : Hasil Penelitian

\section{h. Penyimpanan Dokumen dan Rekaman}

\section{Penerapan Administrasi Pengawasan Produksi}

\section{a. Pengawasan Produksi oleh Planner}

Dalam hal pengawasan, planner bertanggungjawab dalam mengawasi jalannya proses produksi dan jika ada permasalahan yang timbul sehingga dapat dicarikan solusi yang tepat dan dapat diselesaikan secepat mungkin. Dan juga untuk memastikan bahwa produksi berjalan sesuai dengan mesin yang seharusnya digunakan dan berdasarkan perencanaan yang telah disusun oleh planner sebelumnya.

\section{b. Pengawasan Produksi oleh Costumer Service Planner}

Dalam hal pengawasan, costumer service planner bertugas untuk mengawasi kesesuaian jumlah part yang diproduksi di mesin dan juga mengawasi proses produksi tersebut mulai dari mesin hingga disimpan di bagian store/warehouse PT Sanwa Engineering Batam. Costumer service planner juga bertugas untuk mengawasi pengiriman barang/part tersebut kepada costumer, mulai dari jumlah part yang seharusnya dikirim dan juga waktu dan tanggal pengiriman yang diminta oleh costumer.

\section{Fungsi-fungsi Organisasi Terkait}

a. Fungsi Organisasi yang dilakukan Planner

1. Perencanaan (planning)

Dalam hal perencanaan, planner pada PT Sanwa Engineering Batam bertanggungjawab mulai dari :

- Menghitung kapasitas mesin yaitu melalui perhitungan cycle time, output per day dan ouput per hour berdasarkan standar bill of material (BOM) yang telah ditetapkan oleh perusahaan.

- Merencanakan jumlah produksi yang akan diproduksi melalui pengurangan dari jumlah part yang dipesan dengan jumlah inventory yang tersedia di gudang perusahaan.

- Merencanakan mesin yang akan dipakai dalam proses produksi yaitu berdasarkan mesin yang sesuai dengan tonnage biasa part tersebut diproduksi.

- Merencanakan dan membuat suatu jadwal produksi harian (daily production schedule) berdasarkan urgensi dari part tersebut.

\section{Pengorganisasian (organizing)}

Seorang planner yang bekerja di PT Sanwa Engineering Batam dalam hal kegiatan pengorganisasian bertanggungjawab dalam mengorganisasikan dokumen yang diterimanya dan mengolahnya menjadi sebuah jadwal produksi yang baik sehingga dapat dilaksanakan oleh karyawan yang bekerja di bagian produksi PT Sanwa Engineering Batam.

\section{Pengarahan (actuating)}

Dalam hal pengarahan, seorang planner melakukan kegiatan untuk mengarahkan bagian production office untuk melakukan produksi berdasarkan jadwal produksi (daily production schedule) yang telah disusun berdasarkan tanggal pengerjaan dan target yang ingin dicapai. Jika ada kekurangan atau kerusakan mesin atau masalah yang dihadapi, maka planner juga bertanggungjawab dalam mengarahkan staff atau karyawan yang berkepentingan yang dapat mengatasi permasalahan yang terjadi agar cepat mencarikan solusi dan mengatasi permasalahan sehingga proses produksi dapat segera dilanjutkan.

\section{Pengawasan (controlling)}

Dalam hal pengawasan, planner bertanggungjawab dalam mengawasi jalannya proses produksi dan jika ada permasalahan yang timbul sehingga dapat dicarikan solusi yang 
tepat dan dapat diselesaikan secepat mungkin. Pengawasan juga dilakukan untuk memastikan bahwa produksi berjalan sesuai dengan mesin yang seharusnya digunakan dan berdasarkan perencanaan yang telah disusun oleh planner sebelumnya.

\section{b. Fungsi Organisasi yang dilakukan Costumer Service Planner}

\section{Perencanaan (planning)}

Dalam hal perencanaan, costumer service planner hanya bertugas sebagai pendukung dari seorang planner yaitu untuk memperjelas tanggal pengiriman dan juga jumlah barang yang akan diproduksi berdasarkan kekurangan barang yang ada di gudang (store) dengan barang yang dipesan oleh costumer.

\section{Pengorganisasian (organizing)}

Dalam hal pengorganisasian, seorang costumer service planner bertugas untuk mengumpulkan seluruh data dan informasi yang diterima dari costumer dan mengolah data tersebut serta mengecek kelengkapan, kesesuaian dan kebenaran data tersebut berdasarkan aturan yang dibuat oleh perusahaan. Selanjutnya costumer service planner juga bertanggungjawab dalam menginput data tersebut ke dalam sistem Navision yang digunakan oleh perusahaan sehingga apabila staff atau karyawan ingin melihat suatu transaksi maka mereka dapat mengecek transaksi tersebut di dalam sistem.

\section{Pengarahan (actuating)}

Dalam hal pengarahan, seorang costumer service planner bertugas untuk mengarahkan bagian store dalam hal pengiriman barang agar sesuai dengan waktu dan tanggal yang diminta oleh costumer dan juga sesuai dengan jumlah part yang dipesan oleh costumer tersebut.

\section{Pengawasan (controlling)}

Dalam hal pengawasan, costumer service planner bertugas untuk mengawasi kesesuaian jumlah part yang diproduksi di mesin dan juga mengawasi proses produksi tersebut mulai dari mesin hingga disimpan di bagian store/warehouse PT Sanwa Engineering Batam. Costumer service planner juga bertugas untuk mengawasi pengiriman barang/part tersebut kepada costumer, mulai dari jumlah part yang seharusnya dikirim dan juga waktu dan tanggal pengiriman yang diminta oleh costumer.

\section{Bagan Alur Administrasi Perencanaan dan Pengendalian Produksi}

Gambar 3 Bagan Alur Administrasi Perencanaan dan Pengendalian Produksi

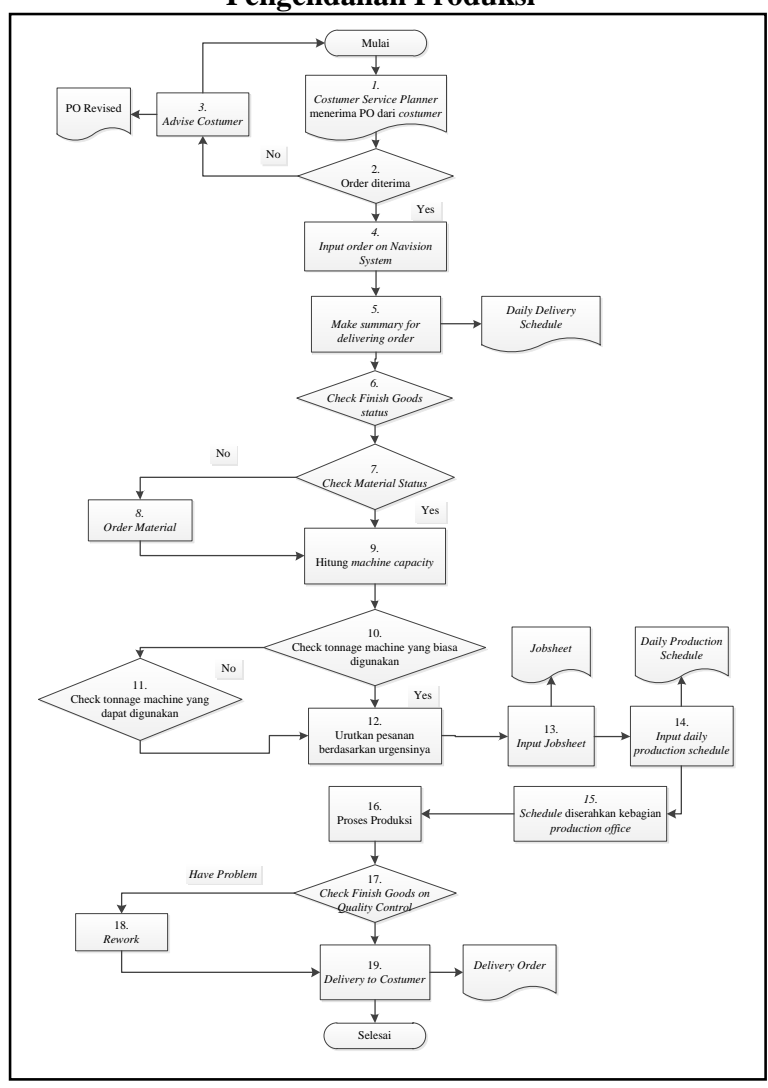

Sumber : Hasil Penelitian

\section{Tinjauan Praktis}

\section{a. Strengths (Kekuatan)}

Tinjauan praktis dalam penerapan administrasi perencanaan dan pengendalian produksi di PT Sanwa Engineering Batam dalam hal kekuatan/strengths yaitu :

1. PT Sanwa Engineering Batam merupakan salah satu perusahaan moulding terbesar di Batam yang sudah berdiri sejak tahun 1993 dan sudah termasuk perusahaan yang sudah diakui dan juga memiliki banyak costumer

2. Planner yang merencanakan produksi dan menyusun jadwal produksi sudah termasuk karyawan yang lama dan sudah ahli dalam hal menyusun rencana produksi dan dapat mengatasi segala permasalahan yang timbul

3. Mesin yang digunakan dalam memproduksi part sudah sangat memadai dan termasuk mesin yang canggih sehingga dapat menghasilkan produk terbaik dengan kualitas sesuai dengan yang telah diharapkan 
Puthri \& Dwi, Studi tentang Penerapan Administrasi Perencanaan dan Pengendalian...

4. Tenaga ahli mold/tooling yang bekerja di PT Sanwa Engineering Batam sudah diakui dan memang ahli dalam hal penanganan permasalahan yang terjadi pada mesin dan mold

b. Weakness (Kelemahan)

Kelemahan/weakness dari penerapan administrasi perencanaan dan pengendalian produksi pada PT Sanwa Engineering Batam yaitu sebagai berikut :

1. Kurangnya rasa tanggungjawab karyawan dalam melaksanakan tugas dan tanggungjawabnya sehingga apabila ditanyakan sesuatu persoalan, sebagian karyawan justru melemparkan tanggungjawabnya terhadap rekan kerja yang lain dan informasi sulit didapatkan

2. Terkadang ditemukan ketidakcocokan antara jumlah barang di gudang dengan jumlah barang di sistem Navision karena ketidaktelitian karyawan atau staff dalam menginput data setiap transaksi yang dilakukan

\section{c. Opportunities (Kesempatan)}

Dalam hal kesempatan yang mungkin saja didapatkan oleh PT Sanwa Engineering Batam yaitu kesempatan untuk berkembang dan menjadi perusahaan lebih besar lagi dengan dukungan mesin yang canggih sehingga dapat meningkatkan profit perusahaan karena PT Sanwa Engineering Batam sudah berdiri sekitar 24 tahun.

\section{d. Threats (Ancaman/Hambatan)}

Hambatan atau ancaman yang dihadapi oleh PT Sanwa Engineering Batam yaitu :

1. Persaingan yang ketat antara sesama perusahaan manufaktur khususnya di bidang moulding karena di Batam sendiri banyak perusahaan sejenis yang juga memproduksi part atau barang yang sejenis

2. Persaingan harga antara sesama perusahaan yang bergerak dalam bidang manufaktur sehingga apabila suatu costumer ingin memesan part maka costumer tersebut akan membandingkan harga antar perusahaan lain yang sejenis

\section{SIMPULAN DAN SARAN}

\section{Simpulan}

Hasil dari pembahasan pada penelitian ini yaitu :

1. Penerapan administrasi perencanaan dan pengendalian produksi pada PT Sanwa Engineering Batam sudah cukup baik dan berjalan dengan lancar karena dikerjakan oleh seorang planner yang sudah cukup berpengalaman dan mengerti bagaimana membuat suatu rencana produksi yang baik dan tepat waktu sehingga tidak terbengkalai dan dapat dikirim sesuai dengan waktu yang diminta oleh costumer.

2. Bagan alur proses perencanaan dan pengendalian produksi pada PT Sanwa Engineering Batam perlu diadakan pembaharuan maka dari itu dalam penelitian ini juga bertujuan untuk merancang suatu bagan alur (flowchart) baru yang lebih detail mengenai tahapan-tahapan kegiatan perencanaan dan pengendalian produksi yang diterapkan di PT Sanwa Engineering Batam

3. Dokumen dan informasi yang dibutuhkan pada proses perencanaan dan pengendalian produksi sudah cukup baik dan mudah di dapatkan apabila diperlukan dan didukung oleh sistem Navision yang digunakan dan di terapkan pada PT Sanwa Engineering Batam sehingga apabila seorang staff/karyawan ingin melihat sebuah transaksi maka dapat mencari pada sistem Navision Batam.

\section{Saran}

Saran yang dapat diberikan untuk perusahaan setelah melakukan penelitian ini adalah :

1. Perusahaan sebaiknya memperbaharui setiap alur yang biasanya dilakukan karyawan agar pada saat ada staff maupun karyawan baru yang diterima bekerja di perusahaan dapat melihat alur detail yang lebih mudah dimengerti seperti salah satu nya adalah alur proses perencanaan dan pengendalian produksi. Alur tersebut hanya menggambarkan dasar dari proses tanpa memberikan penjelasan secara detail mengenai setiap proses yang biasanya dilakukan. Karena dari pengamatan yang dilakukan penulis adalah setiap costumer memiliki cara dan metode sendiri dalam melakukan pemesanan dan juga sistem yang digunakan berbeda-beda.

2. Pembagian tugas dan tangungjawab yang jelas sehingga karyawan dapat menjalankan tugas dan tanggungjawabnya dan dapat mempertanggungjawabkannya sesuai dengan kewajibannya dan ruang lingkup tugas

\section{Keterbatasan}

Penelitian ini hanya membahas tentang penerapan administrasi perencanaan dan 
pengendalian produksi yang dilakukan oleh staff dan karyawan di bagian Production Control (PC) di PT Sanwa Engineering Batam dan tidak membahas tentang pemesanan material dan quality issue. Penelitian ini juga hanya mengambil studi kasus tentang alur perencanaan dan pengendalian produksi untuk PT XYZ yang merupakan salah satu costumer PT Sanwa Engineering Batam. Sehingga pada penelitian selanjutnya dapat memperluas pembahasan maupun ruang lingkup penelitian.

\section{UCAPAN TERIMAKASIH}

Penulis berterima kasih kepada Tuhan Yesus Kristus yang telah memberikan kebaikan, kesehatan, kesabaran dan karunia-Nya kepada penulis. Penyusunan skripsi ini tidak terlepas dari bimbingan dan bantuan berbagai pihak. Pada kesempatan ini, penulis mengucapkan terima kasih kepada:

1. Orang tua saya yang selalu memberikan motivasi dalam menyelesaikan skripsi ini dan juga untuk Julius Albertino yang selalu memberikan semangat dan telah banyak membantu saya

2. Dosen pembimbing saya Ibu Dwi Kartikasari dan dosen penguji saya Ibu Rusda Irawati dan Bapak Aditya Wirangga

3. Teman saya Maria Goretti Pakpahan, Yulianti Harianja, Monalisa Sijabat dan Bellayanni Sulastri dan juga teman-teman seangkatan Administrasi Bisnis A

\section{DAFTAR PUSTAKA}

Cheng, W. \& Liu X. B. (2013). Integrated Production Planning and Control: A Multi-objective Optimization Model. Journal of Industrial Engineering and Management. 6(4).815-830.

Deitiana, T. (2011). Manajemen Operasional Strategi dan Analisa Services dan Manufaktur. Jakarta: Penerbit Mitra Wacana Media.

Fahmi, Irham. (2014). Manajemen produksi dan Operasi. Bandung: Penerbit Alfabeta.

Fatmawati \& Wiwi, U. (2013). Analisis Kapasitas Produksi Dengan Metode Capacity Requirement Planning (CRP) di PT Hanil Jaya Stell. JTM 1(2). 351-354. .

Hadiguna, R. A. \& Machfud. (2008). Model Perencanaan Produksi Pada Rantai Pasok Crude Palm Oil dengan Mempertimbangkan Preferensi Pengambil
Keputusan. Jurnal Teknik Industri. 10(1). 38-49.

Kusdi. (2011). Teori Organisasi dan Administrasi. Jakarta: Penerbit Salemba Humanika.

Kusuma, H. (2009). Perencanaan dan Pengendalian Produksi. Jakarta: Penerbit ANDI Yogyakarta.

Fithri, P. \& Berlian, Y. (2015). Pengelolaan Persediaan Barang Suku Cadang (Spare Parts) pada gudang PT Semen Padang. Jurnal ilmiah Teknik Industri. April. 1-42.

Prihantoro, C. Rudy. (2012). Konsep Pengendalian Mutu. Bandung: PT Remaja Rosdakarya Offset.

Rangkuti, F. (2015). Teknik Membedah Kasus Bisnis Analisis SWOT. Jakarta: PT Gramedia Pustaka Utama.

Ridhotullah, S. \& Jauhar, M. (2015). Teknik Membedah Kasus Bisnis Analisis SWOT. Jakarta: Prestasi Pustakaraya.

Siswandi. (2011). Aplikasi Manajemen Perusahaan Analisis Kasus dan Pemecahannya (edisi 3). Jakarta: Penerbit Mitra Wacana Media.

Sulayman, Yunita, Velany \& Palit, Herry C. (2013). Rancangan Sistem Perencanaan Produksi dan Pengendalian Persediaan dengan Mempertimbangkan Efisiensi Biaya Pada PT X. 1. 165-170. 